\title{
THE IMPORTANCE OF AGRICULTURE IN THE RENEWABLE ENERGY PRODUCTION IN POLAND AND THE EU
}

\begin{abstract}
Summary
The study attempted to assess the importance of agriculture in the process of renewable energy development in Poland and the EU. It was pointed out that, despite the large production potential, the share of agriculture in the production of renewable energy is relatively small in many countries, including Poland. It was stressed that a special role in the process of renewable energy production in agriculture can be played by agricultural biogas plants. Production of agricultural biogas is not only a way to generate renewable energy but also a manner for reduction of methane emissions, usually taking place when manure is stored on the farm. This is particularly important from the point of view of the EU's climate policy. The experience of many countries shows that the growth in importance of renewable energy, particularly in the early stages of development of specified technology depends on the support by public funds. Available statistics suggest that the EU Member States present very different approach to the policy of RES support. In some EU countries (including Poland), a large part of public funds is directed to support "traditional" energy based on fossil fuels.
\end{abstract}

Keywords: renewable energy, agriculture, RES support.

JEL Cods: O13, Q16, Q22, Q42.

\section{Introduction}

The issues of renewable energy sources are recently one of the most often disputed problems referring to both the natural environment and the economy. The so-called Climate and Energy Package, implemented in the European Un- 
ion countries, assumes that by 2020 , as compared to 1990 , emissions of greenhouse gases will reduce on average by $20 \%$, and the share of renewable energy sources (RES) in the total energy consumption will increase by $20 \%$ (Directive 2009/28/EC). The 2014 EU framework for climate and energy policies provides for further limitation in emissions of greenhouse gasses (GHGs) by $40 \%$ against 1990 and increase in the share of energy from renewable sources to the level of at least $27 \%$ in its total consumption by 2030 (European Commission, 2014). In case of Poland, the share of RES expected by 2020 should amount - in line with the aforementioned Directive - to at least $15 \%$. It needs to be added, however, that due to the slow pace of emission reduction, the European Commission prepared a Proposal for a Regulation (European Commission, 2016), which sets out additional targets as regards GHGs emission reductions from the non-ETS ${ }^{1}$ sector by 2030. For Poland, this means emission reduction by $7 \%$ against 2005 . Taking into account the fact that the non-ETS sector includes for instance agriculture, it may be expected that the issues of emissions from agriculture will become increasingly more relevant in the coming years.

According to Eurostat data (2016), in 2014 the share of renewable energy sources in its total consumption in the EU was at an average level of $12.5 \%$, but there were major differences in the field between respective Member States: from $36.2 \%$ in Latvia and 35.8\% in Sweden to 2\% in Malta (Eurostat, 2015). The objectives of Climate and Energy Package, adopted at an international forum, result from the crucial role of the energy sector in greenhouse gas emissions, which - in turn - are recognised as one of the key reasons for global warming and climate change. According to data from the World Resources Institute, energy generation in 2012 accounted for over $70 \%$ of the global emission of these gasses (33 563.82 $\mathrm{Mt}$ of $\mathrm{CO}_{2}$ equivalent). A significant share of the energy sector in the greenhouse gas emissions causes that also the search for methods to reduce it largely goes back to this part of power engineering. However, it is increasingly more often emphasised that on the global scale, agriculture accounts for approx. $13.5 \%$ of GHGs emissions upon conversion into the carbon dioxide equivalent (IPCC, 2007). In the EU, the factor is estimated at 9.8\% (Eurostat, 2012). From the total volume of GHGs emissions from agriculture nearly half directly results from animal farming and the other half from plant production. Basic components of gas emissions from animal production include intestinal fermentation in animal organisms (mainly ruminants) and the management of organic fertilisers created in the production cycle. The main GHGs emitted by agriculture are methane and nitrous oxide, whose impact on greenhouse effect is, accordingly, 23 and 310 times stronger than the impact of carbon dioxide (Mirosz et al., 2015). The issues of the impact of agriculture on the greenhouse effect has not been the subject of intense public debate yet, but the increasingly

\footnotetext{
${ }^{1}$ Emission Trading Scheme - scheme for greenhouse gas emission allowance trading.
} 
more often press news on the issue suggest that it can be gaining ground in the coming years and the criticism of agriculture as an activity harmful to the environment will probably intensify (Teraz Środowisko, 2014, www.wyborcza. biz.pl, 2016). The role of agriculture in the field becomes especially vital given the previously mentioned requirements in the area of emission reduction from the non-ETS sector. Meeting them will require changes in the production technologies or restrictions in the scale of activity in some agricultural production branches.

Agriculture is a major energy consumer (in case of Poland obtained mainly from fossil resources) whose share in the entire energy balance in Poland is estimated at approx. 6\% (http://ozerise.pl/). The agricultural sector is not only the emitter of greenhouse gasses and energy consumer but also has the potential to generate renewable energy. What is more, some types of RES installations (agricultural biogas plants) can be both a source of renewable energy and to some extent can affect reduction in the emission of GHGs from agriculture due to a more efficient use of animal faeces, which are the source of methane emissions (Mirosz et al., 2015). From the report drawn up at the request of DG Agri (Pedroli and Langeveld, 2011) it results that agriculture in the EU is a sector of the economy, which produces more energy from RES than it consumes, and it simultaneously has a major contribution to implementation of the EU climate and energy policy objectives.

Given the complexity of the issues linked to energy generation and its impact on the natural environment, the main purpose of the paper was definition of the most important factors shaping the possibilities of renewable energy development in agriculture.

\section{Agriculture versus energy production}

The Polish legal system defines renewable energy sources ${ }^{2}$ as "renewable, non-fossil energy sources covering wind energy, solar radiation energy, aerothermal energy, geothermal energy, hydrothermal energy, hydropower, energy of waves, currents and tides, energy obtained from biomass, biofuels, agricultural biogas and bioliquids" (Act, 2015). Figure 1 schematically presents the existing types of renewable energy pointing to an agricultural source.

Solar radiation is a vital source of renewable energy on Earth. The solar energy reaching the Earth greatly exceeds the available annual resources of other types of renewable energy, and also total reserves of all types of fossil fuels (Leszczyński, 2010). It is estimated that the amount of solar energy reaching Earth exceeds the

\footnotetext{
${ }^{2}$ Referring to the issues of definition it should be emphasised that very often the term of renewable energy "source" is equated with its resource, but to be precise it seems justified to differentiate renewable energy resources from its sources. A resource should be rather linked to an energy carrier (e.g. water), while energy source refers to a device converting this energy into more useful forms (e.g. hydroelectric power plant).
} 
demands of humans for energy over 5 thousand times (Michalski, 2006). Only approx. $0.02 \%$ of solar radiation power reaching Earth is used to produce energy in solar power plants worldwide (Swatowska, 2016), which is caused by low efficiency of available technological solutions. The Sun is not only a source of solar radiation used in solar collectors and photovoltaic cells, but also a source of energy used in nature for such phenomena as evaporation processes, precipitation, surface water flows or movement of air masses (Klugmann-Radziemska, 2008). The Sun is also the source of energy in the photosynthesis processes, thus it is the primary source of energy contained in different types of biomass. Therefore, the use of biomass is a biological method for conversion of energy from solar radiation (Hermann, 2006). It should be emphasised that biomass, as an energy carrier, is a very mixed category and as such it can be converted in many ways. Biomass can be used for energy purposes, in the processes of direct burning of solid biofuels (wood, straw), conversion into liquid fuels (esters of rapeseed oil, alcohol) and to produce biogas (agricultural, landfill, from wastewater treatment plants). Biomass conversion into usable forms of energy can be done by physical, chemical and biochemical methods (Adamczyk et al., 2010).

According to Gradziuk (2015), biomass generated in agriculture to produce energy, liquid and gaseous fuels is one of the more prospective directions of RES use. In this context special attention should be given to the possibility to convert biomass from agriculture into energy in agricultural biogas plants, which - because of their fragmentation - can contribute to more sustainable development of rural areas and create opportunities for securing new incomes (Gradziuk, 2015; Directive 2009/28/EC). The development potential of agricultural biogas plants (apart from a number of economic conditions) is also conditioned on environmental provisions. At this point, it should be mentioned that the draft Act of 2016 (Rządowe Centrum Legislacji, 2016) on amendment of the Act on fertilisers and fertilisation (Act, 2007) assumes that entities running large-scale animal production (above 40 thousand poultry stands, above 2 thousand stands for pigs weighting over $30 \mathrm{~kg}$, or over 750 thousand stands for sows) can sell up to $30 \%$ of slurry and manure, while the rest should be managed on the owned UAA or allocated to agriculture biogas production. In this context, the establishment of agricultural biogas plants can be for many very large-scale pig and poultry farms one of few possibilities to manage animal faeces created in the animal production process.

Because of a major variety of renewable energy resources possible to be processed in agriculture, this sector can play an important part both as regards energy generation and implementation of climate policy objectives linked to reduction in the emissions of GHGs and growth in the share of RES in final energy consumption to the levels set in the assumptions of the EU climate and energy policy (Directive 2009/28/EC). In line with the applicable methodology of calculating GHGs emissions, set forth in the principles of the "Community 
Emissions Trading", energy generation from biomass is treated as zero emission activity (KOBiZE, 2014). This means that each unit of energy obtained from fossil fuels replaced with energy from biomass leads to emission reduction and increase in the share of renewable sources in final energy consumption. Energy generation from renewable resources can be seen as one of the methods to improve the economic situation of farmers from different parts of the EU (Pedroli and Langeveld, 2011).

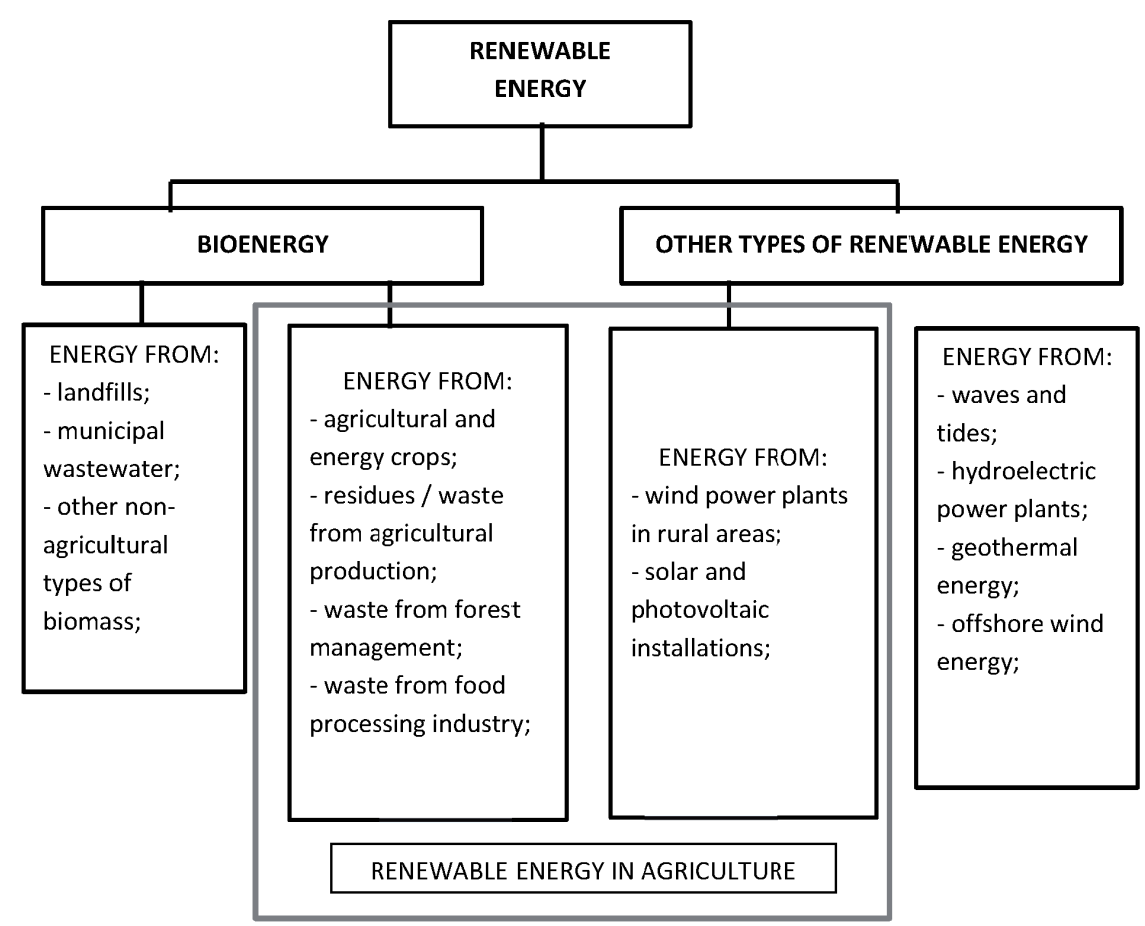

Fig. 1. Types of renewable energy resources considering the role of agriculture.

Source: Burrell, 2010.

In 2014, a total share of solid biomass (including wood) in primary energy ${ }^{3}$ from RES was on average at almost $48 \%$ in the EU countries (Fig. 2). Additionally, approx. 6\% in the total amount of primary energy from RES in 2014 was energy from liquid biofuels and approx. $7 \%$ - energy from biogas, i.e. also raw materials of agricultural origin, only approx. $30 \%$ of biogas generated in the EU was landfill biogas and biogas from wastewater treatment plants (EuroObservER,

\footnotetext{
${ }^{3}$ Primary energy is energy included in primary energy carriers obtained directly from natural renewable and non-renewable resources. Renewable primary energy means energy obtained from natural, constantly repeating natural processes.
} 
2014). At the same time, it needs to be emphasised that the rural areas are also one of the main places of wind and solar energy conversion into electricity. Considering the total potential, the agricultural sector can be seen as the basic renewable energy supplier across the economy.

The structure of energy from RES (including the share of biomass) in respective EU countries is highly differentiated (Fig. 2). Apart from countries such as Poland or the Baltic countries, where solid biomass plays a crucial part, it is also possible to point to countries where renewable energy is based on other resources, wind energy (Ireland) or solar energy (Cyprus, Malta). What should be also mentioned are countries such as the Netherlands or Germany, where the share of solid biomass in energy production from RES is relatively low, but also other energy sources, mainly of agricultural origin, play a major part (biogas and biofuels being a more processed form of biomass).

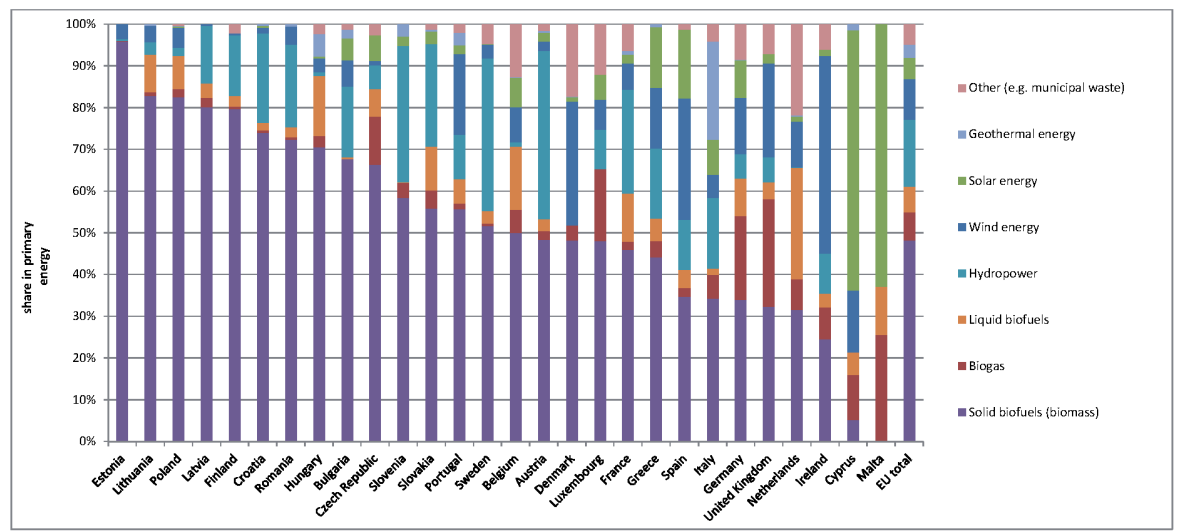

Fig. 2. Structure of primary energy from renewable sources in the EU countries in 2014. Source: Eurostat, 2014.

Despite the dominating share of solid biomass in the structure of renewable energy in the EU countries, it is clear that its relative significance from the beginning of the current century decreases, although there is a growth in the absolute level of energy production from this carrier. In 1990, in the EU-28 countries approx. 40 Mtoe (megatonnes of oil equivalent) of energy was obtained from solid biomass, which was nearly $60 \%$ of the total energy from renewable sources. Whereas in 2014, the amount of primary energy obtained from solid biomass was already at over 85 Mtoe, but this was only approx. $43 \%$ of total energy from renewable energy sources (Fig. 3). Simultaneously, there is a clear growth in the significance of wind and solar energy, which is a global trend linked to subsidisation and a drop in energy production costs from these sources, and also better energy efficiency of photovoltaic and solar installations (Gradziuk, 2015). 
Considering the energy from biogas and liquid biofuels in the biomass, the total share of biomass in renewable energy in 2014 was at a level close to earlier years (approx. 59\%). This points not only to biomass substitution with other types of RES but also to growing significance of more advanced methods of its processing, such as biogas technology or liquid biofuels, for which the primary energy source is still solid biomass (most often of agricultural origin).

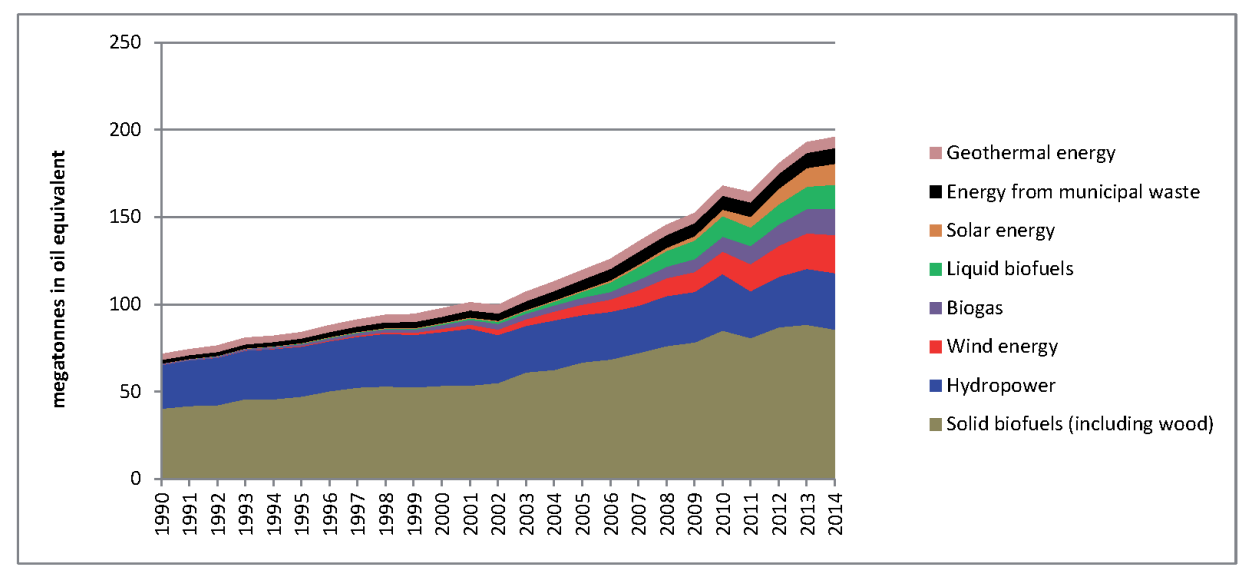

Fig. 3. Changes in the amount and structure of primary energy from RES by types of carriers in the EU countries in 1999-2014.

Source: Eurostat, 2016.

A large share of biomass in the structure of energy generated from RES causes that agriculture and forestry are at the same time, sectors of the economy which have a total of almost $60 \%$ share in primary energy obtained from renewable sources in the EU (Fig. 4). Presently, the forestry sector has a key significance in the comparison. The last available Eurostat data (2013) indicate that on average in the EU the share of agriculture in the structure of primary energy obtained from RES was in 2010 at $10.6 \%$, while the share of forestry exceeded $48 \%$. Both a total share of agriculture and forestry in the primary energy from RES as well as relations between the two components differ greatly between respective countries. Agriculture played the most important part as regards renewable energy production in Belgium (30.8\%) and in Germany (over 27\%) and the lowest in Estonia and Sweden (respectively, by $0.3 \%$ and $1.3 \%$ ), while in Estonia the share of the forestry sector in renewable energy production was the highest in the entire EU.

In Poland, the share of agriculture in the primary renewable energy was at $6.3 \%$. Whereas in terms of the use of large amounts of forestry biomass to produce energy, Poland was ranked second among the EU countries as regards the 
significance of forestry, whose share in primary renewable energy was at $85 \%$ in 2010. Additionally, academic discussions draw attention to validity of restricting the share of forestry biomass for the increase in the share of agricultural biomass (Kuś et al., 2009). It needs to be also noted that forests are one of the more efficient ways of the $\mathrm{CO}_{2}$ capture, and the government of the Republic of Poland suggests to include the element into the emission calculations on equal terms as other measures taken up in the field of $\mathrm{CO}_{2}$ emission reduction (in the EU ETS calculations) (Ministerstwo Środowiska, 2016).

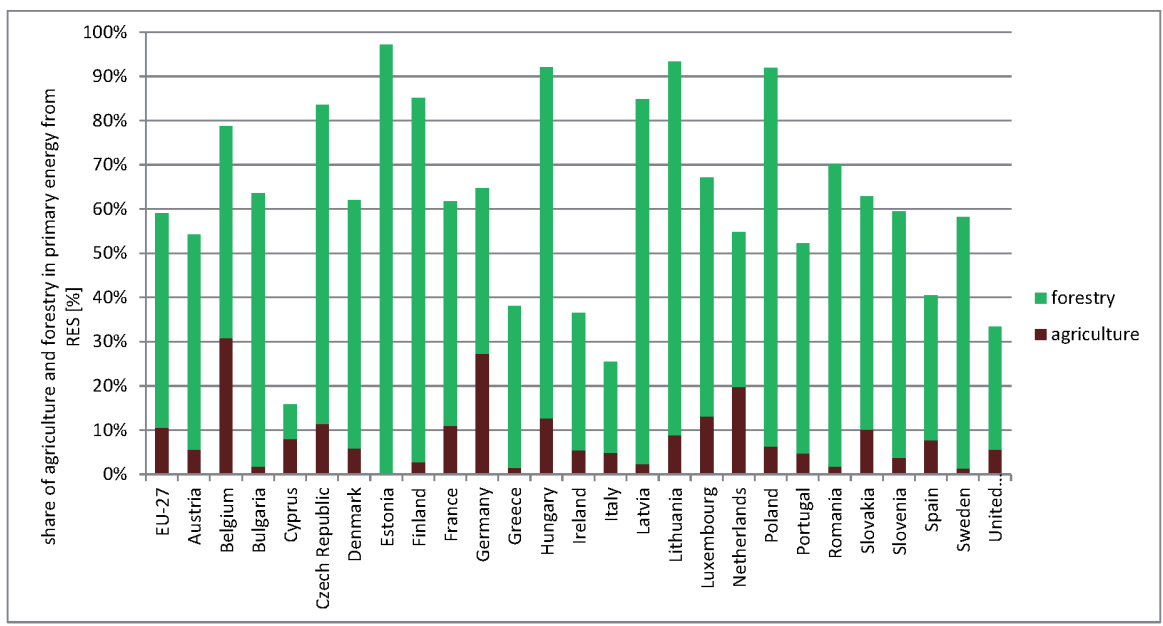

Fig. 4. The share of agriculture and forestry in primary energy from RES.

Source: Eurostat, 2013.

Despite the fact that agriculture and forestry taken together show a major share of primary energy obtained from RES, it should be emphasised that in relation to primary energy obtained throughout the energy sector the indicators are at a rather low level, especially in case of agriculture. On average, the two sectors in the EU had approx. 10\% share in total primary energy production in 2010 (Eurostat, 2013) out of which only $2.1 \%$ fell to agriculture (Fig. 5). Countries basing largely on energy from forestry and agriculture include mainly the Baltic countries and Portugal, Finland, Luxembourg, Austria and Sweden (in each of the above-mentioned countries the total share of forestry and agriculture exceeds $40 \%$ of primary energy). In case of Poland, the share of agriculture and forestry in the total amount of energy was at a lower level than the EU average ( $8.7 \%$ share of forestry and $0.65 \%$ share of agriculture). 


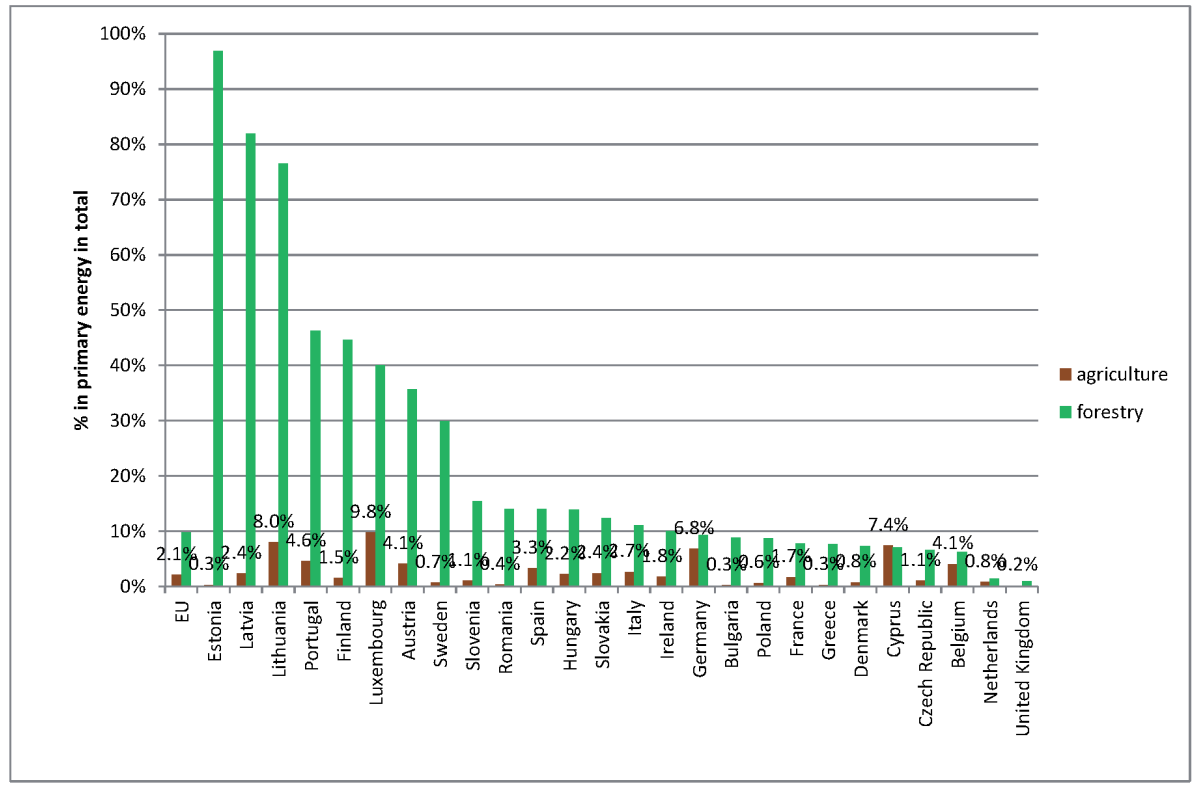

Fig. 5. The share of agriculture and forestry in total primary energy production in the EU. Source: Eurostat, 2013.

Despite minor share of agriculture in the total primary energy production, it needs to be emphasised that the amount of energy obtained by the sector in the EU gradually grows. It should be, however, noted that there are major differences between respective countries as regards share of agriculture in energy production - over $90 \%$ of energy produced by the EU sector was produced in the countries of the so-called "old EU" (EU-15) and half of it in Germany only. Figure 6 presents changes in the amount of renewable energy produced by agriculture for selected EU countries. In 2010, the Polish agriculture, according to the available data, produced 435 ktoe (kilotonnes of oil equivalent) of primary renewable energy, which means a share at the level of $2.5 \%$ in the production of the entire EU agriculture. According to Elbersen et al. (2010), the total energy potential of biomass of agricultural origin can be estimated in the EU at 123536.1 ktoe, out of which 10.6\% (i.e. approx. 13152.2 ktoe) falls to Poland (higher energy production potential from biomass according to the quoted authors is typical only of Germany, the United Kingdom, France and Italy). 


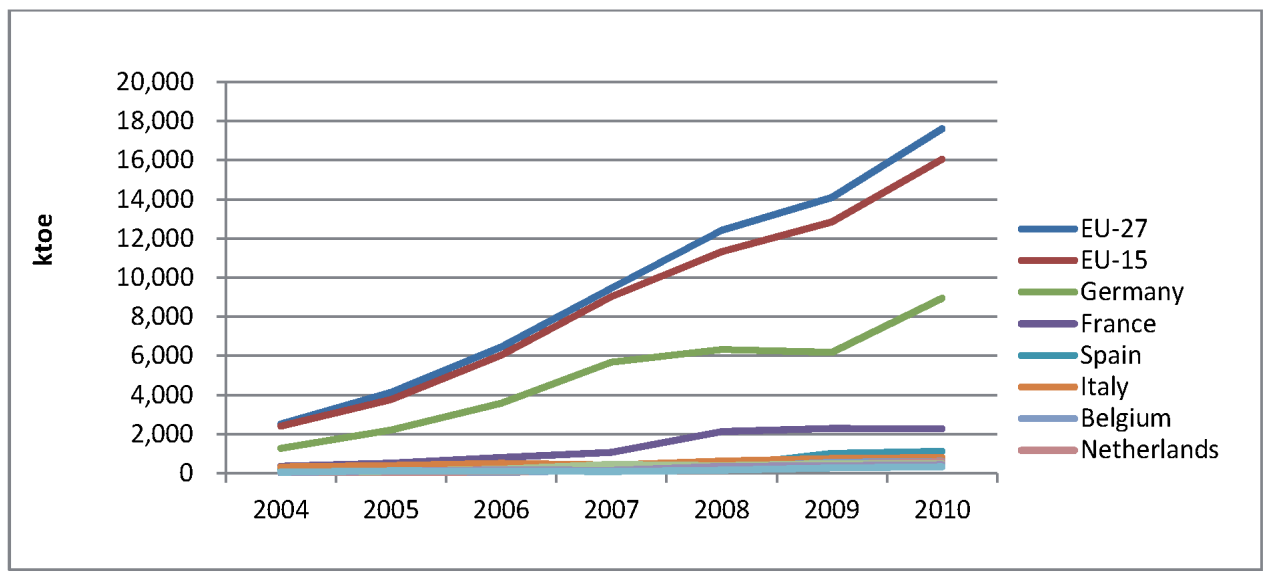

Fig. 6. Primary energy from renewable resources obtained in agriculture in the selected EU countries.

Source: Eurostat, 2013.

\section{Financial support and development of renewable energy in agriculture}

Available analyses and comparisons show that costs of obtaining energy from RES are still higher than costs of energy production from conventional sources. For example, Figure 7 presents a comparison of $\mathrm{LCOE}^{4}$ for different sources of energy in Germany (Kost et al., 2013). Only in some types of RES the level of costs can be considered as similar (Lazard, 2014). From the above example of Germany, it follows that the cheapest energy sources still include coal, and one of the more expensive is still energy obtained from biogas incineration. With reference to the costs of energy obtaining from biomass, it needs to be added that depending on the applied technology of biomass processing the level of energy costs can differ significantly between different regions of the world.

However, it can be expected that in the coming years there will be a drop in energy production costs from renewable sources and, at the same time, a growth in energy costs from fossil fuels (Kost, 2013). This will be conditioned by e.g. growing requirements in the field of environmental protection. As a practical example, we can use the changes in wind and solar energy generation costs in the USA, which between 2009 and 2014 dropped, respectively, by nearly $60 \%$

$\overline{{ }^{4} \text { LCOE - Levelized Cost }}$ of Electricity - unit averaged cost of electricity production per lifecycle $(\mathrm{PLN} / \mathrm{kWh})$ calculated according to the formula: LCOE $=\frac{\sum_{t=0}^{N} \frac{\left(I_{t}+M_{t}\right)}{(1+r)^{t}}}{\sum_{t=0}^{N} \frac{E_{t}}{(1+r)^{t}}}$; where: $I_{t}$ - investment outlays in t-th year; $M_{t}$ - operation costs and financial costs of a loan in $\mathrm{t}$-th year; $E_{t}$ - electricity production in t-th year; $r$ - interest rate. 
and $80 \%$ (Lazard, 2014). It should be also noted that the traditional economic account overlooks the issue of environmental and health costs (externalities), which accompany energy production from fossil fuels (Epstein et al., 2011).

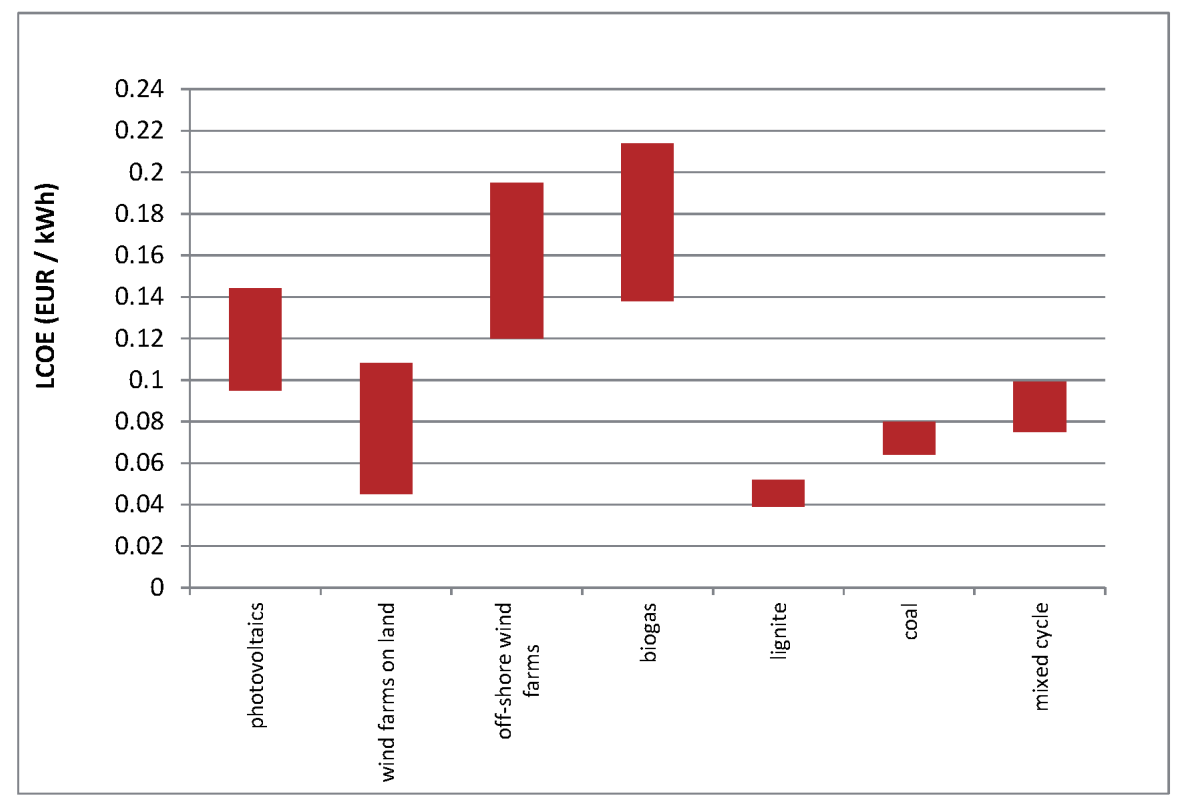

Fig. 7. Average LOCE values for selected sources of energy in Germany in 2013.

Source: Kost et al., 2013.

Relatively higher costs of obtaining energy from most of RES as compared to conventional energy result from, e.g.: the inputs for technology development, construction of equipment enabling efficient processing of energy originally accumulated in renewable carriers, and transport to the final consumers (especially in case of dispersed structure of sources). But the overall regularity points to the fact that along with development of a given technology, production costs drop which is linked to the so-called learning curves (Wiesenthal et al., 2012). Schematic interdependencies between the technology development phase and energy production costs was presented in Figure 8. In case of RES, costs reduction is the result of lower costs of providing equipment to installations along with dissemination of technologies as well as a drop in operating and financial costs (IRENA, 2015).

Given the high costs of investments in RES, most of the new energy technologies, which were implemented in practice, were so far strongly subsidised at the initial phases of development (Zillman et al., 2008). Financial support for RES is built into the practical implementation of the concept of public goods, 
which can include e.g. "environmental public goods", such as climate stability, linked to reduction of GHGs and quality of air, and also "social public goods", such as vitality of rural areas (Baldock et al., 2010; Małażewska, 2015). Thus, in a broader context, financial support for RES is justified from the perspective of taking care of common good, which is owned by the entire society.

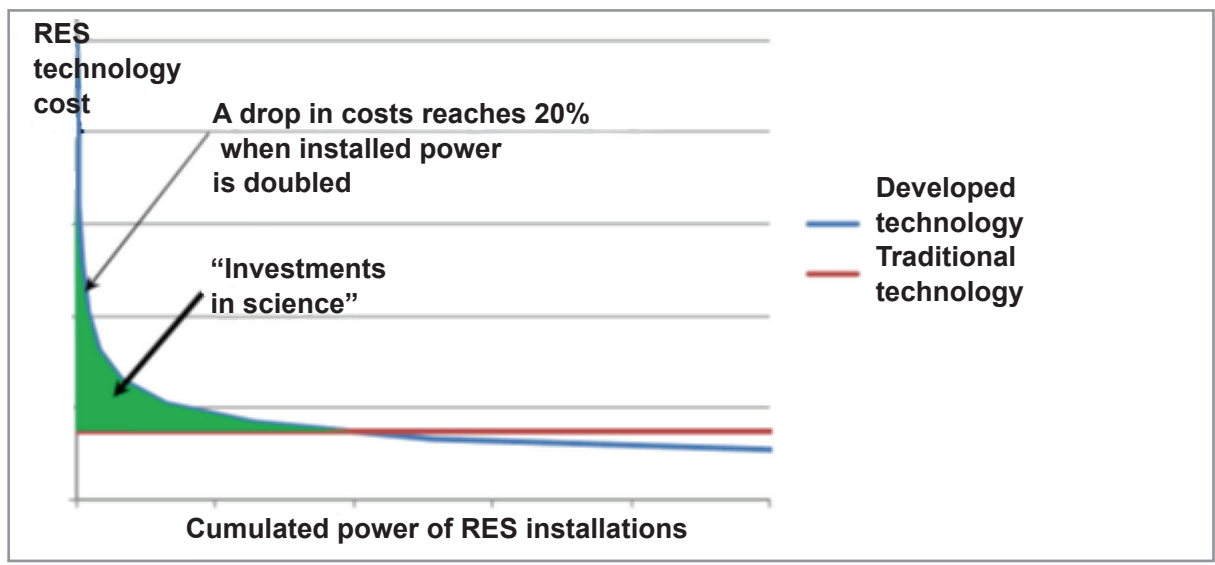

Fig. 8. Schematic illustration of interdependencies between energy production costs and technology development.

Source: Wiesenthal et al., 2012.

It should be emphasised that currently not only energy from RES is subsidised but also energy generation from conventional sources. According to the estimates of the International Energy Agency (IEA), the value of support for energy generation from fossil fuels on the global scale was in 2014 at USD 493 billion, while the total value of support for RES was at that time four times smaller (IEA, 2015). Slightly different relations can be seen in the European Union (Fig. 9). In 2012, the total value of support for energy production from all sources and technologies (including support for conventional sources) in the EU was estimated at EUR 99.4 billion (ECOFYS, 2014). This amount covers both direct support to respective production technologies as well as activities undertaken in the scope of instruments shaping the demand for renewable energy (e.g. tax reliefs) and instruments supporting more economical energy management (e.g. payments to replacement of equipment into more energy efficient one). The share of the two instruments in the overall support value was in 2012, respectively, at $27 \%$ and $8 \%$ (ECOFYS, 2014). In total for direct support for respective renewable energy technologies a little over $40 \%$ was allocated from the total support for the energy sector, and together with indirect support in the form of "instruments increasing support for RES" it was over $65 \%$. Over $16 \%$ of all funds was allocated to the segment basing on fossil fuels, and $6.6 \%$ to nuclear power. Among the renewable energy sources the highest share in distribution 
of support fell to solar energy sector. Obtaining energy from biomass, being the key area of farmers' activity in energy generation, was, on average, only at approx. $8.3 \%$ of the value of all energy subsidies in the EU.

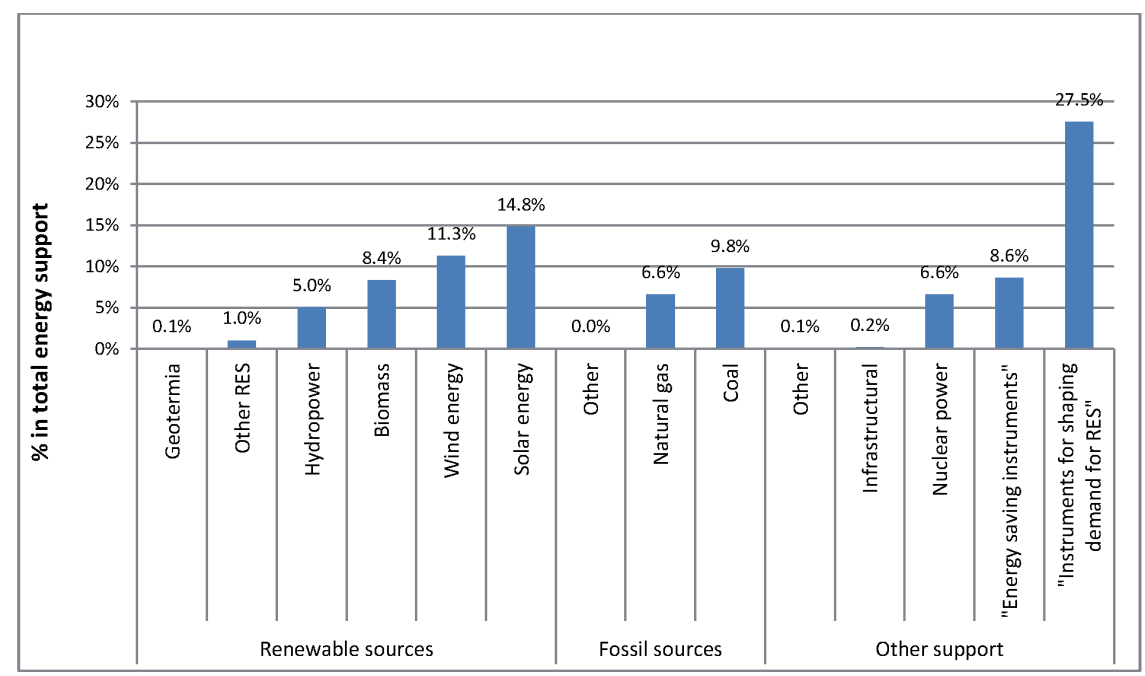

Fig. 9. Share of respective energy sources in distribution of support from the energy sector in the EU in 2012.

Source: own study on the basis of: Subsidies and costs of EU energy Annex 1-3 (Ecofys, 2014).

Figure 10 presents the summed value of support to the energy sector in respective EU countries and the share of support allocated to the sector of traditional fossil fuels ${ }^{5}$. The countries most strongly supporting power engineering in total include: Germany, the United Kingdom, Spain and Italy. Compared to these countries the level of energy sector support in Poland can be assessed as rather low. It is very important in this context that Poland (apart from Ireland) belongs to countries allocating relatively the largest part of support to conventional energy sector. In 2012, according to the available data, nearly $80 \%$ of the value of whole support to the energy sector was allocated to the sector of energy generated from fossil fuels (under different forms of aid). This ratio rather clearly points to priorities in the energy policy existing in Poland, which rather included energy basing on fossil fuels. This ratio needs to be considered as one of the more important determinants shaping also the present development perspectives of the RES sector (including also in the field of agriculture), assuming continuation of the climate and energy policy conducted in the past.

\footnotetext{
${ }^{5}$ Reference to the share of support for the segment of fossil fuels clearly points to emphasis in energy policy of respective countries. The RES, as it follows from earlier comparisons, can be supported by several methods. Aiming at more unambiguous comparison of the situation, it was decided to present on the figure the information on the share of support targeted at energy based on fossil fuels.
} 


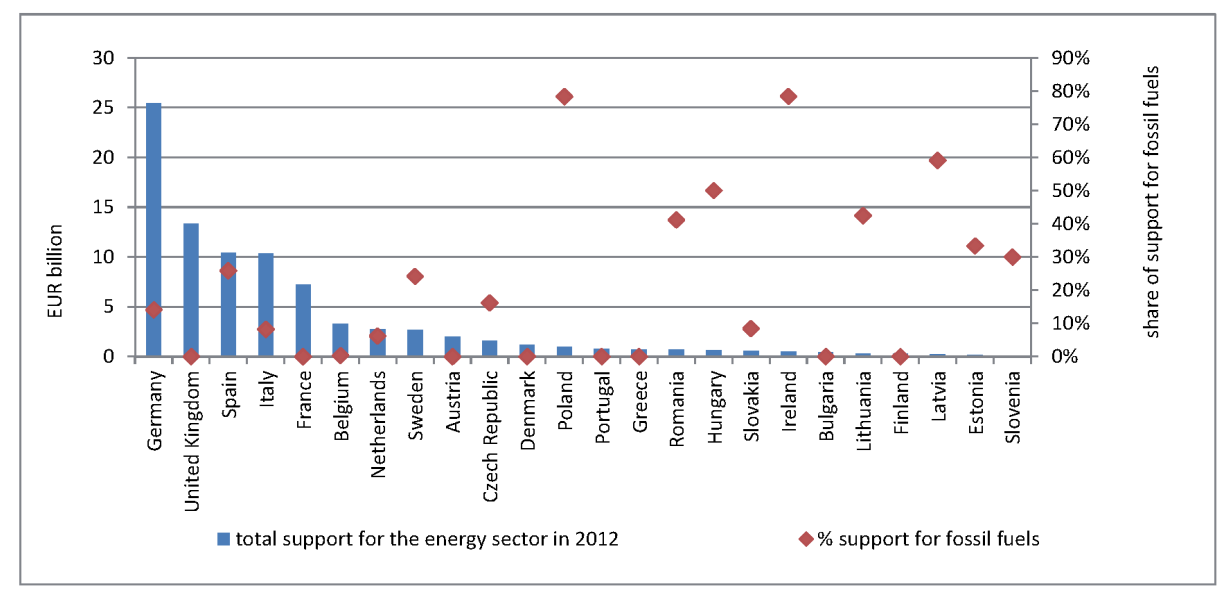

Fig. 10. Total value of support for the energy sector in selected EU countries.

Source: own study on the basis of: Subsidies and costs of EU energy Annex 1-3 (Ecofys, 2014).

The support for renewable energy sources (similar to that for conventional ones) can be done with the use of many different instruments. In general they can be qualified as tools in the form of investment subsidies and operating aid subsidies in the operation period of a given energy source (production subsidies). The crucial among them include:

- Investment grants - cover partial co-financing of investments at the stage of its implementation.

- Feed-in tariffs - consist in energy purchase guarantees from the owner of the RES installation (e.g. farmer) at predetermined prices over a specified time. The instrument was to apply in Poland on the basis of the Act of February 2015 , as regards micro-installations with electric power output up to $10 \mathrm{~kW}$ (which would simply correspond to a small agricultural biogas plant powered by slurry and manure from a herd of up to 30 LUs).

- Feed-in premiums - contrary to feed-in tariffs, do not provide for a fixed price of energy collected for the RES installation and only guarantee a specified payment to the market price.

- The system of energy origin certificates - the so-called green certificates, consists in receiving by energy producers transferable property rights per each energy unit generated from RES. The prices of certificates are set as a result of the game of supply (created by RES energy producers) and demand (notified by producers of energy from conventional sources who when purchasing certificates show achievement of a determined share of RES in its production structure, to which they are obligated by law). The certificate system formed grounds for support for renewable energy sources in Poland by 2016.

- Call for tender - consists in selection under the tender of entrepreneurs declaring provision of energy generated in the RES installation (the entity of- 
fering the lowest price wins). This system is usually intended for installations of increased power (for instance, because of the possibility to achieve scale effects in case of larger facilities).

- Tax reliefs and co-financing of investment loans.

A more detailed characteristic of support instruments for RES energy production used in various countries can be found in, e.g. paper by Held et al. (2013). However, the past experiences as regards support to RES do not permit to state what set of tools can be considered as optimum from the perspective of faced environmental and economic goals. The RES energy support system differs greatly in respective countries. The set of basic instruments considering the type of renewable energy source used in respective countries as regards support for electricity was included in Table 1 (as of 2014). From the perspective of agriculture, the column entitled "energy from biomass" may be considered as the most important. Bearing in mind the frequency of occurrence of respective types of support it can be stated that the most commonly used instrument in the EU countries so far were feed-in tariffs.

Given the significance of agriculture in the development of renewable energy generation, it seems to be important to answer the question about support to the agricultural sector. Lack of available data on RES support divided by types of energy producers much hinders precise response to the question. To simplify, it can be assumed that the key premise for most of the transfers in the area is energy generation from biomass (but farmers can also produce energy from wind). Figure 11 presents the level of expenditures incurred in total by respective EU countries in 2008-2010 on support to energy generation from biomass and the amount of primary renewable energy from agriculture. Despite the fact that agriculture can also generate energy from other sources, there is a rather strong interdependence between the level of financial support for biomass use for energy purposes and the quantity of renewable energy generated in the agricultural sector. The Pearson correlation coefficient in this case is at 0.94 . Only in several cases the quantity of renewable energy generated by agriculture slightly depends on the level of subsidisation of biomass use (France, Spain), which suggests that energy generated in agriculture is based in these cases to a larger extent on other sources than biomass (or that other sources are more strongly supported with public funds). Among the EU countries, definitely the highest level of support for energy production from biomass was typical of Germany that allocated for the purpose in the discussed period over half of the entire support in the EU $(\sim 53 \%)$, which translated also into nearly $50 \%$ of share of the country in renewable energy generated by the entire agriculture of the EU. Whereas countries with relatively low level of support for generation of energy from biomass include Poland, although the quantity of primary energy obtained from agriculture was in this case slightly higher than in other countries with comparable level of subsidisation. This 
may follow from biomass co-incineration practice which - as noted before - is a rather cheap technology and thus enables energy production at lower level of financial support.

Table 1

RES support instruments as regards electricity generation applied in respective EU countries considering the energy source

\begin{tabular}{|c|c|c|c|c|c|c|}
\hline \multirow[b]{2}{*}{ Country } & \multicolumn{6}{|c|}{ Type of energy source } \\
\hline & $\begin{array}{l}\text { Energy } \\
\text { from } \\
\text { biomass }\end{array}$ & $\begin{array}{c}\text { Geothermal Hydrothermal } \\
\text { energy energy }\end{array}$ & $\begin{array}{c}\text { Energy of } \\
\text { oceanic } \\
\text { currents / } \\
\text { tides }\end{array}$ & Other & $\begin{array}{l}\text { Solar } \\
\text { energy }\end{array}$ & $\begin{array}{l}\text { Wind } \\
\text { energy }\end{array}$ \\
\hline Austria & TG & TG, G & & & TG, G & TG \\
\hline Belgium & $\mathrm{ZC}^{-}$ & $\mathrm{ZC}^{-1}$ & & & $\mathrm{ZC}$ & $\mathrm{Z} \overline{\mathrm{C}}, \overline{\mathrm{G}}^{-}$ \\
\hline Croatia & $\mathrm{TG}^{-}$ & $\mathrm{TG}^{-}$ & & & $\mathrm{TG}$ & $\mathrm{TG}^{-}$ \\
\hline Czech Republic & $\mathrm{TG}, \mathrm{DG}$ & $\mathrm{TG}, \mathrm{DG}$ & & & $\mathrm{TG}, \mathrm{DG}$ & $\mathrm{TG}, \mathrm{DG}$ \\
\hline Denmark & $\overline{\mathrm{TG}}, \overline{\mathrm{DG}}$ & & & $\mathrm{TG}$ & & $\mathrm{TG}, \overline{\mathrm{DG}}$ \\
\hline Estonia & $\mathrm{TG}^{-}$ & $\mathrm{TG}^{-}$ & & & T'G & $\mathrm{TG}$ \\
\hline Finland & $\overline{\mathrm{T}} \overline{\mathrm{G}}, \overline{\mathrm{DG}}, \overline{\mathrm{G}}$ & $\overline{\mathrm{G}}$ & & $\overline{\mathrm{G}}^{-}$ & $\mathrm{G}^{-}$ & $\mathrm{TG}^{-}$ \\
\hline France & $\mathrm{TG}, \mathrm{A}^{-}$ & $\mathrm{TG}^{--}$ & & $\mathrm{TG}$ & $\mathrm{TG}, \mathrm{A}$ & $\mathrm{TG}, \mathrm{A}^{-}$ \\
\hline Germany & $\overline{\mathrm{TG}}, \overline{\mathrm{DG}}$ & $\overline{\mathrm{T}} \overline{\mathrm{G}} \overline{\mathrm{DG}}$ & & & TGG, DG & $\overline{\mathrm{TG}}, \overline{\mathrm{DG}}$ \\
\hline Greece & $\mathrm{TG}^{-}$ & $\mathrm{TG}^{-}$ & & & $\mathrm{TG}$ & $\mathrm{TG}^{-}$ \\
\hline Hungary & $\mathrm{TG}^{-}$ & $\mathrm{TG}^{-}$ & & & $\mathrm{TG}$ & $\mathrm{TG}^{-}$ \\
\hline Ireland & $\mathrm{TG}^{-\cdots}$ & $\mathrm{TG}^{-\cdots}$ & & $\overline{\mathrm{TG}}$ & & $\overline{\mathrm{TG}}^{-}$ \\
\hline Italy & $\mathrm{TG}, \overline{\mathrm{DG}}, \overline{\mathrm{Z}}$ & $\mathrm{TG}, \mathrm{DP}, \mathrm{ZC}$ & & & TG, DG & $\mathrm{TG}, \overline{\mathrm{DG}}, \overline{\mathrm{ZC}}$ \\
\hline Lithuania & $\mathrm{TG}^{-1}$ & $\mathrm{TG}^{--}$ & & & $\mathrm{TG}$ & $\mathrm{TG}^{-1}$ \\
\hline Netherlands & $\mathrm{TG}^{-}$ & $\mathrm{TG}^{-}$ & & & $\mathrm{TG}$ & $\overline{\mathrm{TG}}^{--}$ \\
\hline Poland & $\overline{\mathrm{Z}} \overline{\mathrm{C}}^{*--}$ & $\overline{\mathrm{Z}} \overline{\mathrm{C}}^{*--}$ & & & $\overline{\mathrm{Z}} \overline{\mathrm{C}^{*}}$ & $\overline{\mathrm{Z}} \overline{\mathrm{C}}^{*} \bar{*}^{--\cdot}$ \\
\hline Portugal & T' & TG & & $\overline{\mathrm{TG}}$ & $\overline{\mathrm{TG}}$ & $\overline{\mathrm{TG}}$ \\
\hline Romania & $\mathrm{ZC}^{-}$ & $\overline{\mathrm{ZC}}$ & & & $\overline{\mathrm{ZC}}$ & $\overline{\mathrm{ZC}}$ \\
\hline Spain & $\mathrm{TG}^{--}$ & $\mathrm{TG}^{--}$ & & & $\mathrm{T} \bar{G}^{-}$ & $\overline{\mathrm{TG}}^{--}$ \\
\hline Sweden & $\overline{\mathrm{Z}} \mathrm{C}^{--}$ & $\bar{Z} \bar{C}^{--}$ & & & $\overline{\mathrm{Z}} \overline{\mathrm{C}}^{--}$ & ${ }^{-} \overline{\mathrm{Z}} \bar{C}^{-\cdots}$ \\
\hline Ūnited Kingdom & $\mathrm{TG}, \overline{\mathrm{Z}} \overline{\mathrm{C}}^{-}$ & $\overline{\mathrm{T}}, \bar{Z}^{-}$ & $\bar{Z} \bar{C}$ & & $\overline{\mathrm{T}} \overline{\mathrm{G}}, \overline{\mathrm{Z}} \overline{\mathrm{C}}$ & $\mathrm{TG}, \overline{\mathrm{Z}}$ \\
\hline
\end{tabular}

Key: TG - feed-in tariffs; DG - feed-in premiums; ZC - green certificates; G - investment grants.

* Until 2015, from June 2016 the system of call for tenders is in force, which applies to larger installations and the system of the so-called rebates to micro-installations (40 kW power). The key system assumption is resignation from the direct financial support to energy sales. The surplus of energy produced at a given moment can be sent to the power grid and received in the period of increased demand, but in the amount no greater than 70-80\% of what was transferred. Energy, which will not be received from the grid, will be settled at standard wholesale price.

Source: CEER, 2015. 


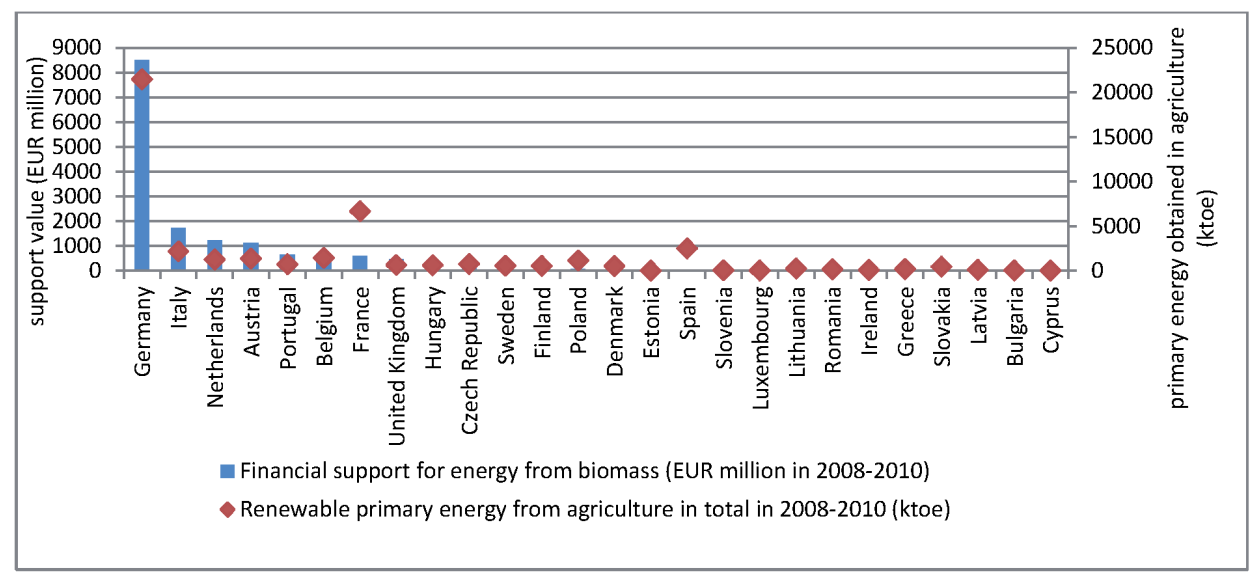

Fig. 11. Financial support targeted at energy production from biomass (EUR million in total in 2008-2010) and the quantity of primary renewable energy from agriculture (Ktoe in total for 2008-2010) in the EU countries.

Source: own study on the basis of: Subsidies and costs of EU energy Annex 1-3 (Ecofys, 2014) and databases of Eurostat (2016).

Given the dependence of renewable energy production on financial support with public funds, it should be emphasised how important are legal regulations concerning RES functioning in Poland. Low efficiency and weak effectiveness of the RES support system binding in Poland from 2005 triggered a search for solutions which would eliminate the existing imperfections and channel real growth in the share of renewable energy in its total consumption. Several years of discussions resulted in a new RES Act of February 2015, which assumed, for instance, introduction of feed-in tariffs for the smallest micro-installations of up to $10 \mathrm{~kW}$ (Act, 2015). The adopted law ensured to such installations the possibility to sell energy at approx. PLN 0.70 per kWh (i.e. slightly higher than the retail price covering the fee for energy and its transfer to the consumer), while the wholesale market price is less than PLN 0.20. This support instrument was to help build the distributed energy system and - as it can be assumed - it could encourage to create RES installations even on rather small farms. The second from the key elements of the new system is based on the call for tender principle. This consists in the fact that the tender for RES energy delivery is won by the producer who offers the lowest energy price - in exchange he gets a guarantee of energy receipt for the next 15 years at the price set during the call for tender. A more detailed interpretation of the assumptions of the Act of 2015 was included in the study by Sulewski et al. (2016). The passed Act has been amended even before entry into force of the key provisions. The amendment adopted in June 2016 replaced the feed-in tariffs system with the so-called rebate system which is a completely new solution. The key system assumption 
is resignation from the direct financial support for energy sales The surplus of energy produced at a given moment can be send to the power grid and received at the time of increased demand, but in the amount no greater than $70-80 \%$ of what had been transferred. This means that creation of renewable energy sources at farms is justified only in case when the generated energy can be used on the very farm (alternatively a group of farms), which greatly limits the importance of RES micro-installations as a source of alternative income for a farmer. Larger producers will still have the possibility to participate in the system of call for tenders, and the call for tender will take place under separated "technology baskets". This will limit the competition between less and more cost-intensive technologies and it can thus positively impact the possibility to develop RES requiring major investment funds, as e.g. agricultural biogas plants of greater production scale than that corresponding to the level of micro-installations.

In the context of the above-described conditions, it should be emphasised that the former experiences suggest lack of long-term and realistic renewable energy development strategy in Poland. Given the scale of renewable energy support in different countries having greater experience with RES generation (including agricultural biogas plants) it can be stated that in Poland the level of support is unusually low and most of the financial resources supporting the power sector is targeted at fossil fuels. In this context, it is difficult to clearly assess the possibility of development of renewable energy based on agriculture (mostly biomass processing). Both forces that can stimulate the development of the sector, and factors hindering it, can be indicated. A comparison of such factors is included in Table 2 . 
Table 2

Factors strengthening and hindering development of renewable energy based on biomass in the Polish agriculture

Factors stimulating renewable energy
development in the agricultural sector
The EU climate and energy policy assumes
further increase in the share of renewable energy
in the "energy mix".
Implementation of the climate and energy
objectives requires reduction in emissions
of GHGs also from agriculture, which is possible,
e.g. through processing of slurry
and manure in biogas plants.

Production of renewable energy (including that basing on biomass) can be the way to diversify farm activity and obtain additional sources of income.

\section{Factors hindering renewable energy development in the agricultural sector}

Implementation of the climate and energy policy objectives is possible also through other (competitive) technologies.

Real possibilities of reducing GHGs emissions from agriculture as a result of building biogas plants refer mainly to the phase of slurry and manure storage (it is possible to exercise pressure to limit the scale of some agricultural activities to reduce emissions for agriculture).

At the present level of RES technology development, support with public funds decides on profitability. Regulations introduced in Poland in 2016 prevent obtaining additional income from RES production by a farm of the smallest scale of energy production.

Renewable energy production costs in a microinstallation are usually much higher than the price of energy purchase from the grid (availability of financial support decided on investment validity), while for larger installations owners are not able to manage the entire generated energy.

Energy generation from biomass, which under normal conditions was ploughed in, leads to deteriorated balance of organic matter in soil, which is unfavourable from the perspective of its yield-forming potential.

disposal.

Launching RES installations based on "dedicated" biomass often leads to reduction in cultivated land resources available for food production.

Unit costs of generation are preconditioned by production scale - farms (even quite large ones) are predisposed to energy production in installations of rather low power and high unit production cost.

The Polish farmers are characterised by a rather low propensity to take up measures of collective character.

Fragmented farm structure hinders creation of larger installations and small biogas plants cannot benefit from financial support to energy production from biogas. suggesting its usefulness in the State energy policy implementation (separate technology basket, "blue certificate").

Source: own study. 


\section{Conclusions}

Energy generation is one of the basic sources of GHGs emissions and, consequently, it is taken as the key factor of climate change. This observation inclined the governments of many countries to support changes in the structure of generated energy, which are most clearly visible in a drive at increasing the share of RES. A major share in the emission structure also belongs to agricultural production, which in the face of the possibilities existing in the field of energy generation speaks for stronger involvement of agriculture in renewable energy production. Although renewable energy in Poland is based mainly on biomass, the agricultural sector is only to a minor degree responsible for obtaining energy. It should be, however, kept in mind that the more intensive use of biomass (especially burning straw) may lead to intensification of unfavourable changes as regards the balance of organic matter in the soil.

The RES technologies at the initial stages of development are much more expensive than energy production from conventional sources, which means that in practice their development is preconditioned by intensity of public support. Support for renewable energy is justified in the context of the environmental concepts of public goods, which include, e.g., climate and air quality. This is especially important in the light of the newest research pointing to the problem of excessive air pollution in Poland (Malec and Borowski, 2016). So far, no universal RES support mechanism has been developed, which would guarantee optimisation of economic and environmental goals and respective EU countries apply different approaches as regards implementation of the climate and energy policy. Poland is among the countries characterised by one of the lowest levels of RES support and the observed growth in the share of this energy in the so-called "energy mix" is largely the effect of co-incineration of biomass in large power units with a large share of biomass from import which in itself undermines the environmental sense behind RES.

The existing model of renewable energy development in Poland can be seen as one of the key factors restricting the possibility of growth of RES significance in agriculture. Given the characteristics of agricultural production, it needs to be stated that the largest possibilities of securing renewable energy in agriculture are linked to biomass processing. In this context what seems especially useful are agricultural biogas plants which enable management of not only residues from plant production but also residues from livestock farming. However, taking into account the new legal regulations and relatively low production scale of the Polish farms, it should be assumed that they will not have the practical possibility of taking part in the system of call for tender. This will exclude them from the possibility of using financial support under the instruments stimulating development of renewable energy. Some alternative is cooperation between farmers and joint creation of larger RES installations (e.g. agricultural biogas plants). But remembering that Polish agriculture is rather reluctant to cooper- 
ate it is difficult to take on such an option as a fundamental solution. From the perspective of the conducted discussions concerning the RES support systems applied in various countries, former history of RES development in Poland and new legal regulations, it needs to be assumed that despite the expectations and "natural predispositions" of agriculture, farms will not become important producers of energy from renewable sources in the coming years. 


\section{Literature:}

Act of 10 July 2007 on fertilisers and fertilisation. Journal of Laws 2007 No. 147 item 1033.

Act of 20 February 2015 on renewable energy sources. Journal of Laws 2015 item 478 as amended.

Adamczyk, F., Frąckowiak, P., Zbytek, Z. (2010). Sposoby wykorzystania biomasy stałej na cele energetyczne. Część 1. Oleje roślinne. Technika Rolnicza i Leśna, No. 5/2005.

Baldock, D., Hart, K., Scheele, M. (2010). Dobra publiczne i interwencja publiczna $w$ rolnictwie. Europejska Sieć na rzecz Rozwoju Obszarów Wiejskich.

Burrell,A. (2010). Renewable energies from the rural sector: the policy challenges. Retrieved from: http://www.oecd.org/greengrowth/sustainable-agriculture/48309185.pdf.

CEER (Council of European Energy Regulators) (2015). Status Review of Renewable and Energy Efficiency Support Schemes in Europe in 2012 and 2013. Ref: C14-SDE-44-03, Brussels.

Ecofys (2014). Subsidies and costs of EU energy. Report to the European Commission.

Elbersen, B., Startisky, I., Naeff, H., Hengeveld, G., Schelhaas, M.J., Böttcher, H. (2010). Spatially detailed and quantified overview of EU biomass potential taking into account the main criteria determining biomass availability from different sources. Deliverable 3.3 - Project: Biomass role in achieving the Climate Change \& Renewables EU policy targets. Demand and Supply dynamics under the perspective of stakeholders. IEE 08 653 SI2. 529241.

Epstein, P.R., Buonocore, J.J., Eckerle, K., Hendryx, M., Stout, B.M., Heinberg, R., Clapp, R.W., May, B., Reinhart, N.L., Ahern, M.M., Doshi, S.K., Glustrom, L. (2011). Full cost accounting for the life cycle of coal. Annals of The New York Academy of Sciences. Issue: Ecological Economics Reviews.

EuroObserv'ER (2014). Biuletyn Energii Odnawialnej - Biogaz.

European Commission (2014). Communication From the Commission to the European Parliament and the Council. Energy Efficiency and its contribution to energy security and the 2030 Framework for climate and energy policy. COM(2014) 520 final, Brussels, 23.7.2014.

European Commission (2016). Proposal for a Regulation of the European Parliament and of the Council on binding annual greenhouse gas emission reductions by Member States from 2021 to 2030 for a resilient Energy Union and to meet commitments under the Paris Agreement and amending Regulation No 525/2013 of the European Parliament and the Council on a mechanism for monitoring and reporting greenhouse gas emissions and other information relevant to climate change. Brussels, 20.7.2016. COM(2016) 482 final 2016/0231 (COD).

Eurostat (2010). Retrieved from: http://ec.europa.eu/eurostat/statisticsexplained/index.php/ File:Contribution_of_agriculture_to_total_GHG_emissions_(\%25),2010,_EU_27_.png.

Eurostat (2015). Renewable energy statistics. Retrieved from: http://ec.europa.eu/eurostat/ statistics-explained/index.php/Renewable_energy_statistics\#Consumption.

Gradziuk, P. (2015). Gospodarcze znaczenie i możliwości wykorzystania słomy na cele energetyczne w Polsce. Monografie i Rozprawy Naukowe, No. 45. Puławy: IUNG.

Held, A., Ragwitz, M., Gephart, M., Visser, de E., Klessmann, C. (2014). Design features of support schemes for renewable electricity. Ecofys 2013 by order of: European Commission. 
Hermann, W.A. Quantifying global exergy resources. Energy 331(12).

http://cait.wri.org/historical

http://eurlex .europa.eu/LexUriServ/LexUriServ.do?uri=OJ:L:2009:140:0114:0135:PL:PDF

International Energy Agency (2014). World Energy Outlook. Retrieved from: http://www. worldenergyoutlook.org/resources/energysubsidies/fossilfuelsubsidydatabase/.

IPCC (2007). Climate Change 2007. Synthesis Report. Contribution of Working Groups I, II and III to the Fourth Assessment Report of the Intergovernmental Panel on Climate Change. Geneva, Switzerland.

IRENA (2012). Renewable Energy Technologies: Cost Analysis Series. Biomass for Power Generation, Vol. 1, Issue 1/5.

Klugmann-Radziemska, E. (2008). Praktyczne wykorzystanie energii słonecznej. Artykuł w ramach projektu “Odnawialne Źródła Energii Opolszczyzny” No. 1/POKL/8.2.1/2008*.

KOBiZE (2014). Wartości opałowe i wskaźniki emisji $\mathrm{CO}_{2}$ w roku 2012 do raportowania w ramach Wspólnotowego Systemu Handlu Uprawnieniami do Emisji za rok 2015. Warszawa.

Kuś, J. (ed.), Faber, A., Matyka, M. (2009). Uprawa roślin na potrzeby energetyki. Warszawa: Polska Konfederacja Pracodawców Prywatnych.

LAZARD (2014). Lazard's levelized cost of energy analysis - version 8.0.

Leszczyński, T.Z. (2010). Perspektywy energetyki słonecznej w Unii Europejskiej. Ziemia na rozdrożu - artykuł nr 1069.

Malec, A., Borowski, G. (2016). Zagrożenia pyłowe oraz monitoring powietrza atmosferycznego. Inżynieria Elologiczna, Vol. 50, December 2016.

Małażewska, S. (2015). Środowiskowe dobra publiczne w rolnictwie i na obszarach wiejskich. Ekonomia i Środowisko, No. 1(52).

Michalski, M.Ł. (2006). Światowe zasoby energii słonecznej i kierunki ich wykorzystania. Czysta Energia.

Ministerstwo Środowiska (2016). Odpowiedź na interpelację nr 5168 Pana posła Tomasza Nowaka w sprawie włączenia pochłaniania dwutlenku węgla przez lasy do systemu handlu emisjami w Unii Europejskiej K8INT5168. Retrieved from: http://orka2.sejm.gov. pl /INT8.nsf/klucz/658C47ED/\%24FILE/i05168-o1.pdf.

Mirosz, L., Amrozy, A., Trząski, A., Wiszniewska, A. (2015). Co decydenci polityczni powinni wiedzieć o mikrobiogazowniach? Publikacja BioEnerg Farm II. Warszawa: NAPE.

Odnawialne źródła energii (OZE) w gospodarstwach rolnych i mikrosieciach. Retrieved from: http://ozerise.pl/pl/oze-w-gospodarstwach-rolnych-i-mikrosieciach.

Pedroli, B., Langeveld, H. (2011). Impacts of Renewable Energy on European Farmers. Final Report for the European Commission Directorate-General Agriculture and Rural Development, AGRI-2010-EVAL-03.

Rządowe Centrum Legislacji (2016). Projekt ustawy o zmianie ustawy o nawozach i nawożeniu z 20 grudnia $2016 \mathrm{r}$.

Sulewski, P., Majewski, E., Wąs, A., Szymańska, M., Malak-Rawlikowska, A., Fraj, A., Trząski, A., Wiszniewski, A., Amrozy, M. (2016). Uwarunkowania ekonomiczno-prawne i opłacalność inwestycji w biogazownie rolnicze w Polsce. Zagadnienia Ekonomiki Rolnej no. 1/(346). 
Swatowska, B. (2016). Fotowoltaika. Rodzaje ogniw słonecznych. Charakterystyki I-V i diagnostyka ogniw. AGH.cWykład.

Teraz Środowisko (2014). Produkcja mięsa gorsza dla klimatu niż transport. Retrieved from: http://www.teraz-srodowisko.pl/aktualnosci/Produkcja-miesa-gorsza-dla-klimatu-niztransport-329.html.

Wiśniewski, G., Michałowska-Knap, K., Kunikowski, G. (2013). Ocena skutków ekonomicznych utrzymania wsparcia dla technologii wspótspalania węgla z biomasa. Warszawa: IEO.

www.wyborcza.biz.pl: Chińczycy ograniczą jedzenie mięsa. Chcą ograniczyć efekt cieplarniany. Retrieved from: http://wyborcza.biz/biznes/1,147750,20281403,spozycie miesa a efektcieplarniany.html\#ixzz4Eqc3FWpb (access date: 15.09.2016).

Zillman, D.N., Redgwell, C., Omorogbe, Y.O., Barrera-Hernandez, L.K. (2008). Beyond the Carbon Economy. Energy Low in Transistion. New York: Oxford University Press. 
PIOTR SULEWSKI

EDWARD MAJEWSKI

ADAM WAS

Szkoła Główna Gospodarstwa Wiejskiego

Warszawa

\title{
MIEJSCE I ROLA ROLNICTWA W PRODUKCJI ENERGII ODNAWIALNEJ W POLSCE I UE
}

\begin{abstract}
Abstrakt
W opracowaniu podjęto próbę oceny znaczenia rolnictwa $w$ procesach rozwoju energetyki odnawialnej w Polsce $i$ UE. Wskazano, że w wielu krajach, $w$ tym $w$ Polsce, pomimo dużego potencjatu produkcyjnego udziat rolnictwa w produkcji energii odnawialnej jest stosunkowo niewielki. Podkreślono, że szczególna role $w$ procesie zwiększania znaczenia rolnictwa $w$ rozwoju energetyki odnawialnej moga odegrać biogazownie rolnicze. Produkcja biogazu rolniczego stanowi nie tylko sposób na pozyskiwanie energii odnawialnej, ale przekłada się też na ograniczenie emisji metanu powstajacego $w$ trakcie przechowywania nawozów organicznych, co jest szczególnie istotne z punktu widzenia unijnej polityki klimatycznej. Doświadczenia wielu krajów wskazują, że wzrost znaczenia energetyki odnawialnej, zwłaszcza w początkowych fazach rozwoju poszczególnych technologii, uzależniony jest od wsparcia środkami publicznymi. Dostepne dane statystyczne wskazują, że poszczególne państwa UE prowadza bardzo różna polityke $w$ zakresie wsparcia sektora energetyki odnawialnej. W niektórych krajach UE (w tym w Polsce) znaczna czesść środków publicznych kierowano na wsparcie energetyki bazujacej na paliwach kopalnych.
\end{abstract}

Słowa kluczowe: odnawialna energia, rolnictwo, wsparcie OZE.

Accepted for print: 19.04.2017.

Unless stated otherwise all the materials on the website are available under the Creative Commons Attribution 3.0 Poland license. Some rights reserved to the Institute of Agricultural and Food Economics - National Research Institute.

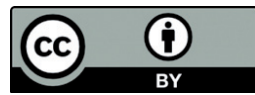

